\title{
Asko Parpola i nowe spojrzenie na początki hinduizmu
}

\author{
Asko Parpola, The Roots of Hinduism. The Early Aryans and \\ The Indus Civilization, Oxford University Press, New Delhi 2015,
} ss. 363

\author{
Robert Czyżykowski \\ Instytut Religioznawstwa \\ Uniwersytet Jagielloński
}

Problem podjęty przez Asko Parpola w jego najnowszej książce poświęconej genezie hinduizmu jest $\mathrm{z}$ pewnością jednym $\mathrm{z}$ trudniejszych i bardziej kontrowersyjnych w studiach indologicznych, religioznawczych oraz indoeuropeistycznych. Autor opiera się na koncepcji istnienia dwóch głównych filarów, na których wyrósł hinduizm: tradycji Indoariów oraz wcześniejszej tradycji rdzennej ludności doliny Indusu. Nowa monografia fińskiego badacza jest nowoczesnym i kompetentnym ujęciem problematyki, co do której - jak sam autor przyznaje - nie ma pełnej zgody specjalistów. Trudno byłoby także znaleźć bardziej doświadczonego i kompetentnego badacza zdolnego podjąć się tego wyzwania. Asko Parpola to emerytowany profesor Uniwersytetu w Helsinkach, indolog i specjalista w zakresie Azji Południowej, o ogromnym doświadczeniu w eksploracji najwcześniejszych etapów rozwoju cywilizacji indyjskiej. Niewątpliwie najbardziej rozpoznawalny jest jako zwolennik hipotezy o drawidyjskim pochodzeniu języka cywilizacji doliny Indusu (dalej: CDI). Był także, razem z Fritsem Staalem, współorganizatorem projektu „Agni” $\left(1975^{1}\right)$. Jest wreszcie również autorem dziesiątków artykułów poświęconych przede wszystkim zagadnieniu pisma i religii CDI, ale również innym zagadnieniom jak między innymi: studia nad Wedami, śaktyzmem, kulturą ludów drawidyjskich ${ }^{2}$. Omawiana publikacja skupia dotychczasowe zainteresowania i osiągnięcia Parpoli w postaci przemyślanego zbioru hipotez obejmujących najdawniejszy okres rozwoju hinduizmu.

${ }^{1}$ Zob. A. Parpola, The pre-Vedic Indian Background of the Srauta Rituals [w:] Agni: The Vedic ritual of the fire altar, F. Staal (red.), vol. II, Berkeley 1983, s. 41-75. C.G. Kashikar, A. Parpola, Śrauta traditions in recent times [w:] Agni: The Vedic ritual..., s. 193-251.

${ }^{2}$ Zob. dorobek autora na stronie: http://www.helsinki.fi/ aparpola/index.html [dostęp: 20.12. 2016]. 
Książka The Roots of Hinduism. The Early Aryans and The Indus Civilization składa się z dwóch głównych części - Early Aryans i Indus civilisation - poprzedzonych obszernym Wprowadzeniem. Taki podział w ogólnych zarysach odzwierciedla także dwuczłonową hipotezę o genezie hinduizmu jako wypadkowej kultury Indoariów i spadkobierców cywilizacji doliny Indusu. Analiza zawartości poszczególnych rozdziałów umożliwi nam przedstawienie poglądów autora i wyników jego badań w zdyscyplinowany sposób. Rozdziały części wprowadzającej (rozdz. 1-5) zawierają podstawowe informacje dotyczące rozpatrywanych w dalszej części książki tematów i stanowią doskonałe podsumowanie współczesnej wiedzy o wczesnej kulturze Indoariów oraz CDI. W rozdziale szóstym autor dokonuje przeglądu teorii dotykających jednego z najbardziej kontrowersyjnych, a zarazem kluczowych problemów w historii indoeuropeistyki, a mianowicie pierwotnej siedziby proto-Indoeuropejczyków. Rozdział jest świetnym podsumowaniem zagadnienia od najwcześniejszych koncepcji Theodora Benfeya, Ottona Schradera, V. Gordona Childe'a, przez Mariję Gimbutas, aż po współczesne postacie, takie jak James P. Mallory, Walentin Dergaczew i David Anthony. Stykamy się tutaj przede wszystkim z teoriami wyrosłymi na polu archeologii i lingwistyki. Kluczowym zagadnieniem dla problemu powstania hinduizmu i rozwoju kultury Indoariów jest w tym przypadku udomowienie konia oraz użycie technologii wozu i rydwanu. Ich pojawianie się, zdaniem Parpoli, stanowi podstawowe kryterium identyfikacji kultury Indoeuropejczyków. Gdziekolwiek pojawiają się te elementy, czyli technologie związane z użyciem koła, zwłaszcza rydwan, i można jednocześnie zidentyfikować adekwatne dla tych technologii słownictwo, tam z całą pewnością mamy do czynienia z Indoeropejczykami. Parpola uważa, że leksyka języka protoindoeuropejskiego (PIE) denotująca pojazdy kołowe to najbezpieczniejsze kryterium identyfikacji siedziby późnych plemion posługujących się PIE $^{3}$.

W kolejnym, siódmym rozdziale Parpola omawia szczegółowo obecny stan wiedzy dotyczącej wczesnych Indoeuropejczyków na eurazjatyckim stepie. Prawdopodobnie miejscem powstania indoaryjskiej gałęzi ludów indoeuropejskich jest późna kultura grobów jamowych. Sama separacja dwóch gałęzi językowych pierwotnej wspólnoty Indoirańczyków nastąpiła, jego zdaniem, około 2500 roku p.n.e. Kolejno przechodzimy wraz z autorem przez analizy kultury Abasjewo i Potapowkę, by dłużej zatrzymać się nad potężną kulturą Sintaszta, a następnie przejść do omawiania kultur Petrowka i Andronowo (pomijam tu analizowane inne ważne kultury stepowe). Parpola podsumowuje ten wątek, formułując założenia dotyczące dyfuzji języka PIE, co ma ważkie konsekwencje dla właściwego rozumienia fenomenu ekspansji języków indoeuropejskich na subkontynencie indyjskim. Otóż zakłada on ${ }^{4}$, że pierwotna hipoteza o gwałtownej ekspansji militarnej związanej z rozprzestrzenieniem się języków indoeuropejskich nie znalazła potwierdzenia w badaniach. Dyfuzja języków indoeuropejskich odbywać się miała raczej za sprawą migracji małych, ale silnych

${ }^{3}$ Ludy używające PIE (protoindoeuropejski) musiały wejść w kontakt $\mathrm{z}$ technologią pojazdów zaprzężonych w konie w Azji Centralnej. Dokładne miejsce pozostaje kwestią sporną. Zob. D. Anthony, Horse, Wheel, Language. How Bronze-Age Riders from the Eurasian Steppes Shaped the Modern World, Princeton 2007.

${ }^{4}$ Obecnie dominująca koncepcja - zob. J. Mallory, In Search of the Indo-Europeans: Language, Archaeology and Myth, London 1989. 
grup hierarchicznie zorganizowanych społeczności Indoeuropejczyków. Były one dobrze uzbrojone (nowoczesna broń, konie, rydwany) i zajmowały się handlem produktami luksusowymi. Lokalnym władcom zamiast konfrontacji częstokroć bardziej opłacało się wchodzić z takimi przybyszami w koligacje (wzmocnione często przez małżeństwa, s. 67-68). W ten sposób migracja i handel mogą lepiej tłumaczyć dyfuzję języków indoeuropejskich niż dawne teorie podboju.

Kolejnymi niezwykle interesującymi zagadnieniami omawianymi przez Parpolę, a mogącymi rzucić światło na korzenie hinduizmu są kultury Azji Środkowej oraz leżące na terenie północnej Syrii i Mezopotamii państwo Mitanni. Pośród kultur Azji Środkowej najbardziej znaczącym „przystankiem” na drodze wędrówki Indoariów musiał być tak zwany baktryjsko-margiański kompleks archeologiczny (ang. BMAC). Odkrycia nieznanej dotąd cywilizacji w południowym Turkmenistanie zawdzięczamy rosyjskiemu archeologowi Wiktorowi Sarianidiemu. Najsłynniejszy obiekt tego kompleksu to forteca Togolok-21. Fiński badacz proponuje scenariusz przejęcia przez nomadycznych Ariów zwierzchnictwa nad BMAC. Analiza lingwistyczna nieindoeuropejskich etymologii w Rygwedzie, dokonana przez Franciscusa B.J. Kuipera (383 „obce słowa”) i Alexandra Lubotskiego wskazuje na obecność leksyki związanej być może właśnie z BMAC. Fascynującym elementem układanki dotyczącej szlaku migracji Indoirańczyków jest problem twierdz z Baktrii. Koncentryczne i okrągłe obwarowania - jak sugeruje fiński badacz - jako powiązane z BMAC (jak na przykład Daszly-3, północny Afganistan, około 1900 roku p.n.e.), mogły odegrać istotną rolę w kształtowaniu kultury Indoariów (zob. poniżej). Parpola jest także zwolennikiem rozróżniania etapów migracji Indoariów i rozdzielania kolejnych ich fal. Najwcześniejsza spośród nich (,,atharwedyjska”) nie tworzyła sensu stricte kultury wedyjskiej w dorzeczu Gangesu, ale ponieważ znalazła się na wschodnich jej rubieżach, tworzyła kulturę Wielkiej Magadhy i posługiwała się wschodnioindyjskim dialektem, prakrytem Magadhy (magadhi). Była pejoratywnie określana przez późniejszych Indoariów, związanych z kulturą Rygwedy (fala „rygwedyjska”), mianem czcicieli asurów (s. 150). Niemniej jednak schemat czterech Wed wskazuje na fuzję kulturową na subkontynencie indyjskim tychże dwóch fal migrantów (czyli, odpowiednio: „atharwedyjskiej” i „rygwedyjskiej”). Parpola zastanawia się w tym kontekście, czy słynna bitwa dziesięciu królów z Rygwedy mogła być stoczona nie w Peńdźabie, lecz w Afganistanie.

Parpola zwraca uwagę na bóstwa-bliźnięta, Aświnów, zwanych także Nasatjami, których uważa za dublujących parę Mitra-Waruna. Bóstwa te, jego zdaniem, reprezentują kult charakterystyczny dla pierwszej fali proto-Indoirańczyków, którzy sukcesywnie przejmowali kontrolę nad BMAC (s. 109). Druga fala proto-Indoirańczyków przyniosła z sobą kult Indry i rytuał somy (stąd określenie tej grupy jako somiczna, saumya). Parpola stoi na stanowisku, że ta druga fala migracji wywodzi się z kultury Andronowo, a konkretnie z późnej jej gałęzi określanej jako Fedorowo (około 1400-1200 p.n.e.). Z kolei pierwsza fala ogniskująca się wokół kultu boskich bliźniaków, podróżujących rydwanem Aświnów (tandem - woźnica rydwanu i łucznik), miała mieć za swój boski trunek madhu, czyli „miód”’ W ten sposób dzielą oni

${ }^{5}$ Parpola wskazuje oczywiście na strukturalne odpowiedniki Aświnów w kulturze greckiej (Dioskurowie) i wśród Bałtów (Dieva deli, Dievo suneliali). 
z innymi plemiona indoeuropejskimi kult miodu (madhu, *PIE med.), podczas gdy soma jest zdaniem Parpoli prawdopodobnie nieindoeuropejskiego pochodzenia i została zapożyczona przez późniejszą falę migrujących do Iranu oraz Indii Indoariów

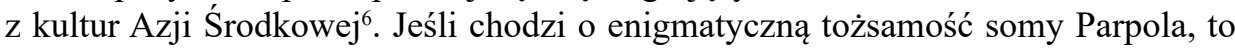
przyjmuje popularną w ostatnich paru dekadach, zwłaszcza wśród indologów, hipotezę o somie jako przęśli azjatyckiej (Ephedra sinica i inne gatunki), zawierającej stymulującą efedrynę7. Rytualne użycie przęśli zaświadczone jest w rytuałach zaratusztrian i niewykluczone, że było stosowane także w BMAC, jak uważa na przykład wspomniany Sarianidi ${ }^{8}$.

Aświnowie reprezentują, zdaniem autora, wczesną fazę rozwoju kultury Indoeropejczyków, w której centralną rolę miał odgrywać rydwan jako prestiżowy pojazd militarny obsługiwany przez dwóch wojowników o równym statusie. Pojawiają się oni także jako bogowie funeralni oraz boscy lekarze. Analizując na podstawie Śatapatha-brahmany rytuał prawargji (pravargya, ofiary z mleka dla Aświnów), Parpola dochodzi do wniosku, że intrygujący element zastępowania głowy nauczyciela Dadhjańca Atharwany (Dadhyan̆c Ātharvaṇa) przez głowę konia ma związek z rytuałem aśwamedhy i - co najważniejsze - swoją wyraźną ilustrację w zapisie archeologicznym w postaci grobu z kurhanu z Potapowki (grób 1, w dorzeczu Wołgi, 2100-1700 p.n.e.) $)^{9}$. Mit ten niewątpliwie odzwierciedla terapeutyczną funkcję Aświnów i zawiera wyraźne odniesienia do kompleksu boskiego „miodu” jako substancji przywracającej życie, a także związanej z nim tajemnej nauki (stąd jednoczesna funeralna i lecznicza funkcja Aświnów). Operacja zastąpienia głowy ludzkiej końską i przywrócenie Dadhjańća do życia mogły stanowić, zdaniem Parpoli, odniesienie do tajemnego rytu ożywiania zmarłego bohatera (s. 122). Odcięta głowa bohatera reprezentowana jest symbolicznie przez dzban/garnek (gharma), co przypomina urny pogrzebowe z kultury Gandhary, podobne do ludzkiej głowy z zaznaczonymi elementami twarzy (oczy, nos, usta).

Niezwykle interesujące są także rozważania Parpoli nad Mahabharata ${ }^{10}$ i kulturami megalitycznymi. Wskazując na obyczaje Pandawów, czyli poliandrię (analogie z irańskimi plemionami Messagatów), umiejscowienie ich pierwszego królestwa na

${ }^{6}$ Jednym z elementów tej układanki byłyby mumie z Xinjiang (zachodnie Chiny, Kotlina Kaszgarska), prawdopodobnie ludności z kultury Andronowo, przy których znaleziono woreczki z prześlą (efedryna). Zob. niżej.

7 Por. na przykład H. Falk, Soma I and II, „Bulletin of the School of Oriental and African Studies”, University of London, 1989, vol. 52, nr 1, s. 77-90. Podsumowanie badań nad somą: R. Czyżykowski, Wedyjska soma - perspektywy badawcze [w:] Narkotyki, dopalacze, środki psychoaktywne. Studia socjologiczne i kulturoznawcze, E. Anczyk (red.), Katowice 2014.

${ }^{8}$ Zob. V.I. Sarianidi, Soma haoma and Margiana, „Electronic Journal of Vedic Studies” 2003, vol. 9, nr 1d (May 5), J. Houben (red.), oraz sceptyczną opinię naukowców z Uniwersytecie w Lejdzie badających materiały z BMAC: C.C. Bakels, Report Concerning the Contents of a Ceramic Vessel Found in the ,White Room” of the Gonur Temenos, Merv Oasis, Turkmenistan, ibidem.

${ }_{9}$ Podobnego zdania jest również M. Witzel, The Home of Aryans, http://www.people.fas.harvard. edu/ witzel/AryanHome.pdf [dostęp: 30.11.2016]. D. Anthony jest także sceptyczny co do hipotezy „centaura”, z uwagi na możliwość pomieszania elementów grobu. Zob. D. Anthony, op.cit., s. 501.

${ }^{10}$ Przypuszcza on, że wydarzenia opisane w Mahabharacie mogły nastąpić w okresie pomiędzy 700 a 350 p.n.e. (królestwo Kuru na $1100-700$ p.n.e.). 
zalesionym obszarze południowej Kurukszetry, a także jasną karnację oraz fakt sojuszu z Kryszną z Mathury, Parpola dopatruje się w nich imigrantów prawdopodobnie z zachodniego Iranu, którzy poprzez Sindh, Gudźarat i Radźasthan mieli przybyć do Azji Południowej. Archeologicznym dowodem takiej migracji byłyby kultury megalityczne (najwcześniejsze z nich to Mahudźhari i Khapa w północno-wschodniej Maharasztrze, około 800 roku p.n.e.). Migracja ta miała się pokryć z granicami wczesnej kultury żelaza w północnych Indiach, czyli „kulturą czarnej i czerwonej ceramiki” (ang. BRWC). Co najważniejsze jednak, badacz wskazuje na powiązanie działalności Pandawów z megalitami w wielu regionach Indii, szczególnie w Tamilnadu, gdzie megality nazywane są pandu-kal, czyli „starymi kamieniami” (s. 149). Protodrawidyjski rdzeń *pal- /*paṇd- („,być starym”) ma homonimicznie zawierać w sobie znaczenie bycia „dojrzałym”, „bladym” (por. z sankr. pandava, czyli ,jasny, blady"). Parpola przeprowadza złożoną argumentację na rzecz tezy o obcym pochodzeniu protagonistów Mahabharaty i próbuje wykryć obecność Pandawów oraz ślady migracji irańskiej w nazwach miejscowości i dynastii (na przykład Pandyu). Eksplorując dalej wątek eposów, problem Pandawów i związanego z nimi kompleksu wisznuickiego, a także kultu „Heraklesa” (zaświadczonego w relacji Megasthenesa, Indica), autor uważa - w odróżnieniu od większości badaczy, a idąc za interpretacją Jamesa Toda - że bóstwo to należy rozumieć raczej jako Baladewę (Baladeva), a nie Krysznę (Herakles jako Hari-kul-esh ${ }^{11}$ ).

Przechodząc do omówienia problematyki dotyczącej cywilizacji doliny Indusu, Parpola oczywiście podtrzymuje swoje przekonanie, że ludność CDI posługiwała się wczesną formą języków drawidyjskich. W opozycji do wielu niewiarygodnych hipotez, jakoby CDI nie znała władzy królewskiej, Parpola argumentuje - i znajduje wiele dowodów na potwierdzenie tej tezy - że w Indusie panowali królowie kapłani. Fiński badacz podkreśla oczywisty fakt kultu wizerunków bóstw wśród agrarnych społeczności doliny Indusu (terrakotowe figurki), co odróżnia je zdecydowanie od Indoariów, którzy nie czcili swoich bogów w postaci materialnych wizerunków. Kluczowy jest problem ukształtowania się ceremonii pudźy (puja), niewątpliwie najważniejszego rytuału hinduizmu. Wiele wskazuje na jego nieindoaryjskie początki. Drawidyjski rdzeń *pucu ${ }^{12}$, oznaczający „,namaszczać”, „smarować”, jest zgodny z centralnym aktem adoracji różnych materialnych form sacrum w hinduizmie podczas pudźi. Dalej akt kąpieli rytualnej również okazuje się mieć nieindoaryjskie początki. Jak argumentuje Parpola, odnosząc się do analogii pomiędzy podobnymi przykładami w dolinie Indusu i późniejszymi obiektami w świątyniach hinduistycznych, woda i jej rytualne użycie w hinduizmie prawdopodobnie wywodzi się z CDI. Baseny kąpielowe przy świątyniach mogły, jego zdaniem, istnieć już w czasach tej cywilizacji. Ponadto powszechny element rytualizmu w południowych Indiach, jak i w dolinie Indusu, to ofiara z bawoła (bawół wodny). Co zaskakujące, ofiara taka nie pojawia się w północnoindyjskiej kulturze Indoariów, co Parpola tłumaczy celowym działaniem w kulturze bramińskiej, aby usunąć taką ofiarę (s. 178).

\footnotetext{
11 Według Cycerona Belus to imię Heraklesa (por. Bala-rama).

12 Por. sanskr.: $\sqrt{ }$ lip, ,smarować” i $\sqrt{ } a \dddot{\jmath}$ - namaszczać - stąd anjalī - rodzaj rytuału wprowadzającego, powitalnego.
} 
Jakie więc elementy wyraźnie poprzedzają religię Indoariów? Parpola wskazuje na starożytny kult jakszów i jaksziń - mitycznych istot związanych z wegetacją, które reprezentują, jego zdaniem, prearyjski kult ludowy wchłonięty przez późniejszy hinduizm i buddyzm. Kult drzewa figowego (banian, ficus religiosa, ficus bengalensis), tak powszechny $\mathrm{w}$ religiach Indii, jest odnotowany na pieczęciach z Harappy, podobnie jak kult wężów (kobry). Kolejnym ważnym elementem, równie często pojawiającym się na pieczęciach CDI, jest ryba. Na pieczęci M-2033B z Mohendźo-Daro antropomorficznemu bóstwu, którego głowa jest przyozdobiona rogami bawołu wodnego, towarzyszą istoty akwatyczne - krokodyl, ryba oraz prawdopodobnie wąż lub symbol wody. Parpola wskazuje tu na usprawiedliwione analogie z sumeryjskim bogiem wody, Enki (s. 181). Akwatyczna symbolika krokodyla (w tym przypadku to konkretny gatunek - gawial gangesowy, Gavialis gangeticus), ściśle wiąże się z rytuałami płodności, obecnymi w hinduizmie od starożytności aż po czasy współczesne. Wiele z tych paraleli pomiędzy zwierzętami przedstawianymi na pieczęciach a czczonymi w hinduizmie uchwycił już odkrywca CDI - John Marschall. Kult krokodyla poświadczony w zachodnich Indiach (Gudźarat) ma być kolejnym dowodem trwałości religii harappańskiej w późniejszym hinduizmie. Głównym zamiarem Parpoli jest próba obronienia tezy o kontynuacji elementów religii doliny Indusu w późniejszych religiach, zwłaszcza w hinduizmie. Niemniej jednak wspomniane elementy religii doliny Indusu trwające w hinduizmie można określić raczej jako przejawy hinduizmu ludowego $\mathrm{i}$ trudno je powiązać $\mathrm{z}$ aspektem tak zwanej Wielkiej Tradycji (,sanskryckiej”).

Kolejnym niezwykle ważnym obszarem powiązania religii harappańskiej i wedyjskiej jest problematyka astronomiczna. Szczególną uwagę zwraca Parpola na problem „siedmiu wieszczów” (wed. sapta ṛşayah - mityczni przodkowie kapłańskich klanów) i utożsamieniu ich z gwiazdami gwiazdozbioru Wielkiej Niedźwiedzicy. Problematyczny w tym kontekście jest termin r rsșah („,niedźwiedź”) i gra słów: rșayah - rkșaḥ. Oczywiście, w innych cywilizacjach ten gwiazdozbiór (Ursa Major) utożsamiany jest również z Niedźwiedzicą. Ponadto Parpola uważa, że koncepcja Gwiazdy Polarnej jako nieruchomego punktu odniesienia, nocnego odpowiednika Słońca, ma swoją genezę w kulturach Azji Południowej. Te rozważania, których nie możemy tu w pełni streścić, skoncentrowane na problematyce astronomicznej i zasadzie ekwiwalencji mikro-makroskomicznej (żółw - Gwiazda Polarna-czaszka - siedmiu mędrców, ekwiwalencja odnotowana już w Brahmanach), doprowadzają Parpolę do hipotezy o przedaryjskim (harappańskim) pochodzeniu jogi (s. 201-209). Owa korelatywna kosmologia wyrażałaby się w paralelizmie tchnień-korzeni niebiańskiego figowca i promieni słonecznymi, co ma swój odpowiednik w ludzkim ciele w postaci sieci subtelnych kanałów (koncepcja obecna we wczesnych Upaniszadach: Bryhadranjaka i Ćhandogja). Występuje tu także, odnotowana w późniejszych źródłach, korespondencja pomiędzy upaniszadowym przypisaniem kolorów do wewnętrznych kanałów a promieniami Słońca i kolorami pięciu planet (s. 311). Sama koncepcja z pewnością nie jest nowa. Przypomnijmy jednak, że dotąd próbowano wiązać genezę jogi w CDI z niejasną interpretacją pieczęci z siedzącym „,protojoginem" (tzw. Protośiwa). Parpola odżegnuje się od tych silnie krytykowanych 
hipotez i uważa, że koncepcje astronomiczne i korelatywna kosmologia są raczej tymi aspektami religii doliny Indusu, które mogą rzucić światło na problem genezy jogi. Należy jednak stwierdzić, że pomimo wyrafinowanej argumentacji, przedstawione przez Parpolę argumenty dowodzące, iż rodowód jogi jest harappański, pozostawiają poczucie niedosytu.

Następnym ważnym obszarem religii doliny Indusu są powiązania z kulturami Azji Zachodniej. Centralnym motywem, wspólnym dla doliny Indusu i Mezopotamii, są częste w ikonografii przedstawienia króla, bohatera lub byka z dwoma lwami po bokach. Parpola uważa, że zwierzęta te - będące symbolami władzy królewskiej, czyli lew i byk, a mające swoje odpowiedniki na nieboskłonie - tworzą kompleks symboliczno-mityczny obecny zarówno w Mezopotamii, jak i w dolinie Indusu. W tym przypadku kierunek dyfuzji określonej symboliki związanej z władzą królewską przebiegałby jednak z Mezopotamii do doliny Indusu.

Szczególnie ważnym i specyficznym dla kultu doliny Indusu mitycznym motywem, który miał przetrwać w hinduizmie, jest pojedynek bogini z bogiem/demonem-bykiem lub bawołem. Wojownicza bogini, która pojawia się w micie o zabiciu przez Durgę demona-byka Mahiszy (Mahișāsura), jest bohaterką jednego z najważniejszych mitów puranicznych. Parpola zwraca tutaj uwagę na paralele z preelamickim przedstawieniem walki pomiędzy lwem uzbrojonym w łuk a bykiem posługującym się maczugą. W indyjskich przedstawieniach bogini Durga, zwana Mahiszasuramardini (Mahișāsuramardini), czyli zabójczyni demona Mahiszy, zabija demona (asurę) Mahiszę włócznią (lub trójzębem), z kolei demon broni się maczugą. Na słynnej płaskorzeźbie z Mammalapuram (Māhābalipuram) z Tamilnadu, będącej jednym z najwcześniejszych przedstawień tego motywu (VII wiek), bogini używa łuku, zaś demon z głową byka dzierży maczugę.

Interesująco brzmią interpretacje tantrycznych rytuałów w perspektywie szerzej rozpatrywanego panindyjskiego kultu bogini i tradycji wedyjskiej - na przykład festiwale, jak śabarotsava, które - zdaniem Parpoli - miały być substratem dla słynnego tantrycznego rytuału „lewej ręki” (vāmācāra lub vāmāmarga), a mianowicie cakra-pudźy (cakra-pūja a), ,rytuału kręgu”. Ofiara z bawołu jest jednoznacznie związana z kultem bogini. Niewątpliwie to fakt, który zauważano już wcześniej w kontekście trwałości kultu bogini na subkontynencie indyjskim od okresu CDI aż po hinduizm puraniczny. Parpola dostarcza jednak dodatkowej argumentacji na rzecz wyjaśnienia problemu interakcji pomiędzy indoaryjskim rytualizmem a rdzennym indyjskim kompleksem rytualnym. Harappański kult bogini był związany z jednej strony z płodnością i żyznością (a także erotyką), z drugiej zaś - ze śmiercią i wojną. Symbolizował go tygrys lub lew (wierzchowiec bogini). Punktem kulminacyjnym tegoż kompleksu rytualno-mitycznego był konflikt bogini z człowiekiem-bawołem (lub bykiem). Zwierzę to mogło również reprezentować małżonka bogini ginącego w noworocznym rytuale. Ten rytualny kompleks i jego symbolika są, zdaniem Parpoli, wspólne dla doliny Indusu i Zachodniej Azji. Argumentuje on za koncepcją trwałości tego kompleksu i kontynuacją kultu harappańskiej bogini w rytuałach atharwedyjskich wratjów (,zurbanizowanych” Indoariów), reprezentujących wczesną falę plemion indoaryjskich migrujących do północnych Indii z BMAC około 
2000-1700 p.n.e. Zdaniem Parpoli, ta rytualizacja miała być substratem rozwoju tantrycznych form kultu bogini indyjskiej, jawiącej się z jednej strony jako krwawa zabójczyni demonów, z drugiej zaś - jako matka i archetyp idealnej żony.

W podobnym tonie jest utrzymany rozdział dwudziesty, zatytułowany Wcześni Irańczycy i tantryzm , lewej ręki”. Parpola rozpatruje tu etymologię imienia Durgi i kompleks twierdzy (bogini „trój-miasta”, tri-purā). Po raz kolejny sięga też w głąb historii proto-Indoirańczyków i opisuje twierdze-świątynie typu Dashly-3 z Baktrii z koncentrycznie opasującymi ją murami. Porównanie planu tego rodzaju twierdz z tantrycznymi mandalami jako kosmogramami symbolizującymi siedzibę władcy-bóstwa ma nas przekonywać o ich genezie, która wiedzie, zdaniem autora, do Azji Środkowej. Parpola utożsamia grupy czczące boginię będącą wzorem dla Durgi z Dasami (Dasjami), Kuszanami i generalnie z Irańczykami napływającymi kolejnymi falami do Indii. Uznaje też transgresywne elementy w rytuale tantrycznym za relikty militarystycznego systemu rytualnego plemion irańskich oraz indoraińskich. Do tych elementów należą: promiskuityzm przed wyprawami wojennymi, gromadzenie trofeów (głów, skalpów) oraz użycie czaszki pokonanego wroga jako naczynia do spożywania krwi i wina. Owe transgresywne składniki rytuału tantrycznego musiały być jednak, jego zdaniem, obecne w Azji Południowej jeszcze przed migracjami plemion irańskich, te zaś jedynie je wzmocniły.

Problem nieodczytanego dotąd pisma doliny Indusu ${ }^{13}$ to niewątpliwie „oczko w głowie" Parpoli. Przypomnijmy, że jest on najbardziej rozpoznawalnym (oprócz indyjskiego uczonego I. Mahadewana) zwolennikiem hipotezy o drawidyjskim pochodzenia pisma CDI, a Deciphering the Indus Script to prawdopodobnie jego najbardziej znana praca ${ }^{14}$. Sztandarowym przykładem jego analizy jest odczytanie znaku ryby, który ma denotować drawidyjskie minn i oznaczać zarówno rybę, jak i gwiazdę. Ponadto znak ryby, który pojawia się często z kropką w jej wnętrzu, przypomina Parpoli kropkę bindu (sanskr. ,punkt, kropka”), czyli czerwony znak malowany na czole w późniejszym hinduizmie, symbolizujący małżeństwo, ale też odnoszący się do kultu bogini (bindu odnosić się może do krwi menstruacyjnej, czyli oznacza płodność). W tym kontekście gwiazdę utożsamia on z czerwoną gwiazdą Rohini (rohini, „,zerwona”) i odnosi się też do zbieżności semantycznych pomiędzy rybą, gwiazdą, czerwienią oraz kropką w językach drawidyjskich (odnosząc się także do innych korelacji astronomicznych i lingwistycznych, które ze względu na brak miejsca musimy pominąć, s. 274-278). Iravatham Mahadevan ${ }^{15}$, którego metoda odczytania pisma

${ }_{13}$ Zob. A. Robinson, Cracking Indus Script, „Nature”, 22 October 2015, vol. 526, s. 499-501. Jedną z bardziej znanych, ale i kontrowersyjnych propozycji jest interpretacja ,pisma CDI” jako zapisu czysto symbolicznego, który nie odzwierciedla zapisu żadnego języka (zespół M. Witzel, R. Sproat, Farmer, The Collapse of the Indus-Script Thesis: The Myth of a Literate Harappan Civilization, „Electronic Journal of Vedic Studies" (EJVS) 2004, vol. 11, nr 2 p. 19-57). W krótką, ale treściwą polemikę z amerykańskimi uczonymi wchodzi Parpola jedynie we Wprowadzeniu do omawianego tu tomu. Szerszą odpowiedź Parpoli znajdziemy w artykule: Is the Indus Script Indeed not a Writing System? [w:] Airāvati. Felicitation Volume in Honour of Iravatham Mahadevan, Chennai 2008.

${ }_{14}$ A. Parpola, Deciphering the Indus Script, Cambridge 2009.

${ }_{15}$ Por. I. Mahadevan, Interpreting the Indus Script: The Dravidian Solution, i obszerną dyskusję na harappa.com [dostęp: 28.12.2016]. 
CDI różni się od Parpoli, dokonuje przeglądu tych i innych interpretacji pisma oraz wskazuje na słabe punkty w rozwiązaniu Parpoli. Fiński badacz uważa jednak swój system wyłącznie za propozycję, otwartą na modyfikację. Dzisiejszy stan badań nie pozwala jednak na żadną konkluzywną opinię o tym starożytnym systemie pisma.

Jakie więc dane religioznawcze wyłaniają się z propozycji Parpoli? Czy jego interpretacja pieczęci na tym etapie może rzucić światło na religie CDI? Zdaniem Parpoli, intepretując pismo z pieczęci jako zapis wczesnego języka z grupy drawidyjskiej w piśmie logosylabicznym i piktograficznym, możemy w zupełnie nowy sposób spojrzeć na kosmologię puraniczną z centralną rolą Gwiazdy Polarnej, kosmicznego drzewa figowego (banjanowca) podtrzymującego ciała niebieskie. Skomplikowana analiza dotycząca takich znaków, jak: „ryba”, „krab” i „,figowiec”, której dokonuje autor, ma prowadzić do wniosku, że tabliczki i pieczęcie z CDI zawierają taką właśnie koncepcję (s. 279-281). W ten sposób otrzymujemy pod wieloma względami nowy obraz wczesnych dziejów hinduizmu w kontekście religii CDI. Drugim filarem tego nowego spojrzenia na genezę hinduizmu byłaby hipoteza o dwóch falach migracji Indoariów - ,atharwedyjskiej” i „rygwedyjskiej”, co pozwala na bardziej precyzyjne datowanie najstarszych tekstów cywilizacji indoaryjskiej i pogłębione zrozumienie interakcji pomiędzy grupami wczesnych plemion indoaryjskich. W ten sposób warstwa mitologiczna hinduizmu również zdaje się mieć zaczepienie w religii doliny Indusu (incest królewski i mit Pradźapatiego-Brahmy uwodzącego własną córkę, Wać, czyli mowę, s. 312). Najbardziej zbliżoną do pierwotnej religii CDI formą hinduizmu byłby kompleks tantryczny śiwaicko-śaktyjski z centralnym kultem ambiwalentnej bogini (aspekt krwawy i erotyczny), wzbogacony o „leworęczne” praktyki atharwedyjskich Dasów. Należy tu jednak stwierdzić, że część argumentacji Parpoli opiera się na dość chwiejnych dowodach. Należą do nich: sekwencja migracji Indoariów, tożsamość somy, grób „centaura”, powiązanie Dasjów z kultami tantrycznymi. To problemy szczegółowe, oddzielne, ale i dyskusyjne, będące jednak elementami budującymi większe hipotezy. Ich falsyfikacja może też zagrozić innym koncepcjom Parpoli zaprezentowanym w omawianej książce.

Podsumowując, książka jest pozycją wysoce specjalistyczną, a jej tematyka z pewnością znajdzie oddźwięk w środowisku indologów, iranistów, indoeuropeistów, archeologów i oczywiście religioznawców. Trudno obecnie znaleźć podobną pozycję monograficzną poświęconą genezie hinduizmu, która wykorzystywałaby tak obszerny materiał archeologiczny i łączyła go z danymi filologicznymi oraz konfrontowała z najnowszą wiedzą indologiczną i religioznawczą, by zbudować dojrzałe hipotezy. Książka Parpoli niewątpliwie wejdzie do zbioru klasycznych pozycji poświęconych najwcześniejszej historii i ewolucji religii Indii. 